\title{
Production of Polypropylene Matrix Polymer Composites with Hazelnut Shell Fillings, Physical and Mechanical Properties
}

\author{
N. A. Gurbanov, I. I. Abbasov, K. H. Ismayilova, and N. A. Hasanova
}

Azerbaijan State Oil and Industry University, Azadlyg, 20,

Az 1010 Baku, Azerbaijan

Natural fibres have been commonly utilized to reinforced materials for many years. Recently due to advantages of natural fibres such as low cost, high physical and mechanical resistance, plastic-composite materials are produced by mixing various proportions. In addition, in plastic composites, natural fibres including agricultural wastes (wheat straw, rice straw, hemp fibre, shells of various dry fruits, etc.) are used. In this study, polymer composites are manufactured using waste nutshell flour as filler and polypropylene (PP) as polymer matrix. The nutshell-PP composites are manufactured via extrusion and compression methods. The final products are tested to determine their tensile, flexural, impact strength properties as well as some physical features such as thickness swelling and water absorptions. The best results are demonstrated by obtained composites containing $30 \%$ nutshell flour. In addition, composites, which are produced with nutshell, provide the values of ASTM D6662 standard. The data collected in our country, which wastes a large portion of nutshell, allow for the evaluation of the production of polymer composites. The incorporation of nutshell flour feasible to produce plastic composites when appropriate formulations are used. As a result, hazelnut shell, which is considered as agricultural waste, can be utilized in polymer composite production.

Натуральні волокна звичайно використовуються для армування матеріялів уже протягом багатьох років. Останнім часом через переваги натуральних волокон, таких як низька вартість, висока фізична та механічна стійкість, одержують пластмасові композиційні матеріяли шляхом змішування в різних пропорціях. Крім того, у пластмасових композитах використовуються натуральні волокна, що включають сільськогосподарські відходи (пшенична солома, рисова солома, волокно з конопель, шкаралупи різних сухофруктів тощо.). У цьому дослідженні полімерні композити виготовлено 3 використанням відходів горіхового борошна як наповнювача та поліпропілену (ПП) як полімерної матриці. Композити горіхової шкаралупи в ПП були виготовлені методом екструзії та стискання. Кінцеві продукти тесту- 
валися для визначення їхніх міцнісних, згинальних, ударних властивостей, а також деяких фізичних характеристик, таких як набрякання товщини та вбирання води. Найкращі результати продемонстрували одержані композити, що містять $30 \%$ борошна горіхової шкаралупи. Крім того, композити, які були виготовлені з горіховою шкаралупою, забезпечували значення за показниками стандарту ASTM D6662. Дані, зібрані в нашій країні, що витрачає більшу частину горіхової шкаралупи, уможливлюють оцінити можливості виробництва полімерних композитів. Включення борошна горіхової шкаралупи можливе при виробництві пластикових композитів з використанням відповідних технологій готування. У результаті оболонка фундука, що вважалася сільськогосподарським відходом, може бути використана у виробництві полімерних композитів.

Натуральные волокна обычно используются для армирования материалов уже в течение многих лет. В последнее время из-за преимуществ натуральных волокон, таких как низкая стоимость, высокая физическая и механическая стойкость, получают пластмассовые композиционные материалы путём смешивания в различных пропорциях. Кроме того, в пластмассовых композитах используются натуральные волокна, включающие сельскохозяйственные отходы (пшеничная солома, рисовая солома, волокно из конопли, скорлупы различных сухофруктов и т.п.). В этом исследовании полимерные композиты изготовлены с использованием отходов ореховой муки в качестве наполнителя и полипропилена (ПП) в качестве полимерной матрицы. Композиты ореховой скорлупы в ПП были изготовлены методом экструзии и сжатия. Конечные продукты тестировались для определения их прочностных, изгибных, ударных свойств, а также некоторых физических характеристик, таких как набухание толщины и поглощение воды. Наилучшие результаты продемонстрировали полученные композиты, содержащие $30 \%$ муки ореховой скорлупы. Кроме того, композиты, которые были изготовлены с ореховой скорлупой, обеспечивали значения по показателям стандарта ASTM D6662. Данные, собранные в нашей стране, которая тратит большую часть ореховой скорлупы, позволяют оценить возможности производства полимерных композитов. Включение муки ореховой скорлупы возможно при производстве пластиковых композитов с использованием соответствующих технологий приготовления. В результате оболочка фундука, которая считалась сельскохозяйственным отходом, может быть использована в производстве полимерных композитов.

Key words: polymer composites, nutshell, physical and mechanical properties.

Ключові слова: полімерні композити, горіхова шкаралупа, фізикомеханічні властивості.

Ключевые слова: полимерные композиты, ореховая скорлупа, физикомеханические свойства.

(Received 4 August, 2018) 


\section{INTRODUCTION}

Forest resources in both the world and our country have dropped due to the increase in the population and consumption. For this reason, it has become so important to use raw materials consciously, to recycle used materials, and to find new resources of raw materials. It is obvious that there is an inevitable imbalance between the demand for wood raw material and the current supply. That is why, instead of wood fibre, the use of agricultural and alternative fibres from other resources has become essential. In our country after the agricultural harvest, the remaining parts either mingle with the soil again or are destroyed by burning. The demands for the evaluation of these wastes in different forms are increasing day-by-day (Cooper and Balatinecz 1999; Rowel 2001; Mengeloglu and Alma 2002).

It is necessary to reduce the amount of waste for a cleaner and liveable environment. This can only be achieved by reducing waste generation, increasing recycling and reuse, and rational use of natural resources. In this context, the ' $3 \mathrm{R}$ ' rule is being tried to carry out in many countries. The purpose here is to reduce the amount of raw material used (Reduce) in order to produce less waste, to ensure that any product is recycled (Reuse), and to recycle the material (Recycle) (Karakush 2008; Hill 2010).

There are approximately 60 million agricultural wastes in our soil and waste generated by $5 \cdot 10^{6} \mathrm{~m}^{3}$ forest industry (Mengeloglu et al. 2002; Kurt et al. 2002; Korucu and Mengeloglu 2007).

Composite production is the most common modification process on polymer materials. Materials formed by combining two or more materials often have properties, which are better than the materials they are composed, and are described as composite (Simonsen 1995; Mengeloglu et al. 2002). Composite sheets, which are formed by the mixing of wood flour and lignocellulosic agricultural wastes (wheat stalks, string, hemp, sugar cane, hazelnut shell, etc.) with thermoplastic based polymers (PE, PP, PVC, PS, etc.), are called thermoplastic based composite materials (Matuana and Heiden 2004; Karakush 2008).

In this study, polymer-composite production is done using pure polypropylene plastic and hazelnut shell flour, and the mechanical and physical properties of the produced material have been investigated.

\section{MATERIAL AND METHOD}

\subsection{Material}

The hazelnut shell used as a filler material for polymer composite production was obtained from Gazakh province and pure polypropylene in the case of granules was used as polymer. 


\subsection{Method}

\subsubsection{Lignocellulosic material production}

The hazelnut shells were turned into flour with the help of Willey mill after had been dried completely in the drying oven. In order to make the size of the filler material effective on the performance of the manufactured material, the flour materials were classified and divided info 4060-80-100 mesh groups with the help of a pound sieve. The lignocellulosic fill material used in this study was taken from the part of the graffiti of 40 mesh size, which is suitable for industrial production.

\subsubsection{The production of polymer composites}

Three different ratios have been used in the production of polymer composites and detailed information about them is given in Table 1.

The prepared hazelnut shell meal and the polymer matrix mixer were homogenized by adhering to the production prescription given in Table 1. After this process, the pellet with a temperature of $170^{\circ} \mathrm{C}$ to $190^{\circ} \mathrm{C}$ and a rate of 40 revs per minute was pulled from a single screw

TABLE 1. Production prescription.

\begin{tabular}{c|c|c}
\hline Composite groups & Shell percentage & Polypropylene (PP), \% \\
\hline PP & - & 100 \\
N1 & 30 & 70 \\
N2 & 40 & 60 \\
N3 & 50 & 50 \\
\hline
\end{tabular}

Notes: $\mathrm{PP}-$ Polypropylene; N-Nutshell + Polypropylene.

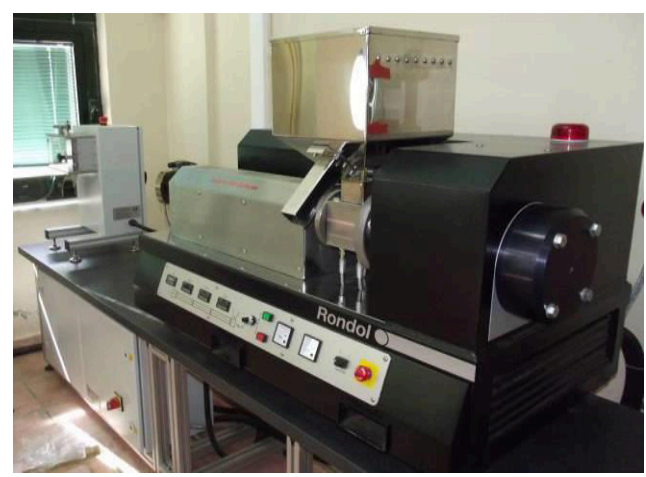

Fig. Extruder machine. 
extruder Rondal and pelletized. The pellets were plated in a hot press heated to $180^{\circ} \mathrm{C}$. Rondal extruder machine is seen in Figure.

\subsubsection{Mechanical tests}

The mechanical properties of the produced polymer composites have been carried out according to the American Standards (ASTM). Bending resistance and tensile strength tests were done using the Zwick/Roell Z010 Universal tester. Bending resistance has been carried out according to the ASTM D 790, and tensile strength for ASTM D 638 standards. Impact resistance tests were conducted according to ASTM D 256 standard with Zwick/Roell HIT 5,5 P machine.

\subsubsection{Identification of physical properties}

Water uptake rate and thickness increments are determined according to ASTM D 1037 and EN 317 standards.

\subsubsection{Statistical method}

The data obtained were analysed using the SPSS packet program and based on a $95 \%$ confidence level. Duncan test was applied to investigate the effect of the obtained differences.

\section{FINDINGS AND DISCUSSION}

SPSS analysis was carried out after making the mechanical test values of the plates formed by adhering to the manufacturing prescription. Firstly, the homogeneity tests were performed, followed by (ANOVA) with $P<0.05$ confidence interval in order to investigate the effect of hazelnut shell flour ratio on mechanical properties. After that, multiple comparisons were performed to determine which sample averages the differences between the groups were subjected to and the DUNCAN test was applied for this purpose. The statistical analysis results and the averages are given in Table 2. As a result of the mechanical tests performed, it became clear that the resistance values fell as the ratio of lignocellulosic material increased.

Mengeloglu and his colleagues made clear that the tensile, bending and impact resistance values in a work using a wheat stalk had close values when compared with the $\mathrm{N} 1$ sample tensile, bending and impact resistance values. Table 3 and Table 4 indicate the mean values for the long-term rates of water uptake and thickness increase of plates produced with lignocellulosic material and thermoplastic polymer. Meas- 
TABLE 2. Mechanical test values and applied ANOVA and DUNCAN test results.

\begin{tabular}{c|c|c|c|c|c}
\hline $\begin{array}{c}\text { Composite } \\
\text { groups, } \\
\%\end{array}$ & $\begin{array}{c}\text { Tensile } \\
\text { resistance, } \\
\mathrm{MPa}\end{array}$ & $\begin{array}{c}\text { Flexibility in } \\
\text { tensile, MPa }\end{array}$ & $\begin{array}{c}\text { Bending } \\
\text { resistance, } \\
\mathrm{MPa}\end{array}$ & $\begin{array}{c}\text { Flexibility in } \\
\text { bending, MPa }\end{array}$ & $\begin{array}{c}\text { Impact } \\
\text { resistance, } \\
\mathrm{J} / \mathrm{m}\end{array}$ \\
\hline $\mathrm{PP}(0 \%)$ & $23.87(1.14) \mathrm{A} 384.52(29.85) \mathrm{A} 32.22(3.01) \mathrm{A} 968.72(87.95) \mathrm{A} 26.74(5.12) \mathrm{D}$ \\
$\mathrm{N} 1(30 \%)$ & $8.34(0.77) \mathrm{B}$ & $248.26(31.62) \mathrm{B} 16.55(1.02) \mathrm{B} 847.24(82.87) \mathrm{B} 72.90(12.89) \mathrm{A}$ \\
$\mathrm{N} 2(40 \%)$ & $6.69(0.31) \mathrm{C}$ & $240.05(14.57) \mathrm{B} 13.86(0.48) \mathrm{C} 822.73(65.44) \mathrm{B} 58.21(6.43) \mathrm{B}$ \\
$\mathrm{N} 3(50 \%)$ & $5.66(0.33) \mathrm{D}$ & $233.22(11.27) \mathrm{B} 11.96(1.80) \mathrm{D} 745.90(94.88) \mathrm{C} 43.55(6.96) \mathrm{C}$ \\
\hline
\end{tabular}

TABLE 3. Thickness increase percentages (\%).

\begin{tabular}{c|c|c|c|c|c}
\hline $\begin{array}{c}\text { Composite } \\
\text { groups }(\%)\end{array}$ & 2 hours & 24 hours & 48 hours & 1 week & 4 weeks \\
\hline PP $(0 \%)$ & 0 & 0 & 0 & 0 & 0 \\
N1 $(30 \%)$ & 0.92 & 1.50 & 1.57 & 2.11 & 3.10 \\
N2 $(40 \%)$ & 0.89 & 4.31 & 2.55 & 3.87 & 5.66 \\
N3 $(50 \%)$ & 1.51 & 4.74 & 5.92 & 9.03 & 11.12 \\
\hline
\end{tabular}

TABLE 4. Water absorption percentages (\%).

\begin{tabular}{c|c|c|c|c|c}
\hline $\begin{array}{c}\text { Composite } \\
\text { groups (\%) }\end{array}$ & 2 hours & 24 hours & 48 hours & 1 week & 4weeks \\
\hline PP $(0 \%)$ & 0 & 0 & 0 & 0 & 0 \\
N1 $(30 \%)$ & 0.43 & 1.37 & 1.66 & 3.77 & 6.74 \\
N2 $(40 \%)$ & 0.62 & 1.93 & 2.37 & 6.12 & 10.60 \\
N3 $(50 \%)$ & 0.56 & 1.90 & 2.57 & 5.86 & 12.83 \\
\hline
\end{tabular}

urements were performed periodically for each plate type at times of 2.24 and 48 hours, 1 and 4 weeks. It was observed that the proportion of thickness rise and water uptake increased with rising ratio of lignocellulosic material in the composites produced.

\section{RESULTS}

In this study, polymer composite was produced by using hazelnut shell meal and polypropylene, which is an agricultural waste. The physical and mechanical test values of the produced composites were determined. It was found that the shock resistance values of all composites using hazelnut shell flour were higher than the shock resistance value of the lean produced using pure polypropylene. It became clear that the rise in the proportion of hazelnut shell flour used in different amounts reduced the 
mechanical values and increased the swelling and water uptake rates to the thickness. It has been determined that the best result is obtained in composites using $30 \%$ hazelnut flour. It was found that the composites produced together with the bending resistance and elasticity modulus values provided the values indicated in ASTM D 6662 (2001).

\section{REFERENCES}

1. ASTM D 1037 (1996), Evaluating Properties of Wood-Base Fiber and Particle Panel Materials, ASTM International (West Conshohocken, PA: 2006).

2. ASTM D 6662 (2001), Standard Specification for Polyolefin-Based Plastic Lumber Decking Boards, ASTM International (West Conshohocken, PA: 2001).

3. ASTM D 256 (2002), Determining the Izod Pendulum Impact Resistance of Plastics, ASTM International (West Conshohocken, PA: 2002).

4. ASTM D 638 (2004), Standard Test Method for Tensile Properties of Plastics, ASTM International (West Conshohocken, PA: 2004).

5. ASTM D 790 (2004), Flexural Properties of Unreinforced and Reinforced Plastics and Electrical Insulating Materials, ASTM International (West Conshohocken, Philadelphia, PA: 2004).

5. P. A. Cooper and J. J. Balatinecz, Agricultural Waste Materials for Composites, Centre for Management Technology Global Panel Based Conference (October 18-19, 1999, Kuala Lumpur, ML).

6. EN 317 (1993), Particleboards and Fiberboards, Determination of Swelling in Thickness after Immersion in Water, CEN (Brussels, Belgium: 1993).

7. M. K. Hill, Understanding Environmental Pollution. $3^{\text {rd }}$ Edition (New York: Cambridge University Press: 2010).

8. T. Korucu and F. Mengeloğlu, Potentials of Agricultural Residues as Raw Materials and Their Alternative Usage Possibilities in Turkey. 24th National Agricultural Mechanization Congress (Kahramanmaras: 2007), p. 297.

9. R. Kurt, A. Karademir, N. S. Çetin, and N. Özmen, Potential Utilization of Wood Residue in Turkey. First International Ukrainian Conference on Biomass (Kiev, Ukraine: 2002).

10. L. M. Matuana and P. A. Heiden, Wood Composites, Encyclopedia of Polymer Science and Technology (2004), vol. 12, p. 521.

11. F. Mengeloğlu and M. H. Alma, KSÜ Fen ve Mühendislik Dergisi, 5, No. 2: 37 (2002).

12. F. Mengeloğlu and M. H. Alma, and N. S. Çetin, Gazi Üniversitesi Orman Fakültesi Dergisi, 2, No. 2: 57 (2002).

13. R. M. Rowell, International Conference on Science and Technology of Composite Materials (2001), p. 29.

14. J. Simonsen, The Mechanical Properties of Wood Fiber Plastic Composites: Theoretical vs. Experimental. Proceedings of Wood Fiber Plastic Composites (Forest Products Society Proceedings: 1995), No. 7293, p. 47. 